DOI: https://dx.doi.org/10.18203/2320-1770.ijrcog20210774

Review Article

\title{
HIV in pregnancy
}

\author{
Gauri S. Kore* \\ Seth G. S. Medical College and KEM Hospital, Mumbai, Maharashtra, India
}

Received: 27 December 2020

Revised: 07 February 2021

Accepted: 09 February 2021

\section{*Correspondence:}

Dr. Gauri S. Kore,

E-mail: gaurikore96@gmail.com

Copyright: $(\odot$ the author(s), publisher and licensee Medip Academy. This is an open-access article distributed under the terms of the Creative Commons Attribution Non-Commercial License, which permits unrestricted non-commercial use, distribution, and reproduction in any medium, provided the original work is properly cited.

\begin{abstract}
HIV is a disease caused by retrovirus (HIV-1 or HIV-2) the that attacks the immune system of the body, leaving it susceptible to various dangerous infections. HIV can have profound effects on pregnancy and pregnancy may in turn cause an aggravation of signs and symptoms HIV.A pregnant woman living with HIV can pass on the virus to her baby during pregnancy, childbirth and through breastfeeding. This is called Vertical transmission of HIV. Without any intervention, the rate of vertical transmission of HIV is as much as $15-45 \%$. National PPTCT program of India run by NACO (National AIDS Control Organization) aims at preventing HIV transmission from mother to child. Women who are known HIV positives or those who are diagnosed as HIV positive for the first-time during pregnancy, are given Triple Dose Anti Retro-viral therapy comprising of Tenofovir, Lamivudine and Efavirenz. Special precautions are taken during their delivery. Whether LSCS is to be performed depends on the indications and on which guidelines are followed. Infant- feeding is advised to be carried out as per the guidelines stated in the PPTCT act so as to minimize the chances of HIV transmission to the infant.
\end{abstract}

Keywords: HIV, Pregnancy, Vertical transmission PPTCT, Anti-retroviral therapy

\section{INTRODUCTION}

HIV (Human Immunodeficiency Virus) infection which is caused by the virus of the same name is a deadly disease that attacks the immune system of the body, leaving it susceptible to various dangerous infections which would have otherwise been combated. If left untreated, the condition progresses to Acquired Immunodeficiency Syndrome (AIDS) which is the End Stage of the HIV infection $^{1}$

A pregnant woman living with HIV can pass on the virus to her baby during pregnancy, childbirth and through breastfeeding. This is called Vertical transmission of HIV and has been a cause of considerable morbidity and mortality among infants. However, by early diagnosis, by exercising proper care measures in the antenatal, intrapartum and post- partum as also post-natal period and taking antiretroviral treatment correctly, the risk of passing on the virus to the baby can be virtually eliminated. ${ }^{1}$

There are 2 types of HIV infections: HIV-1 and HIV-2. HIV-1 has spread globally and it is the most common type of HIV with almost $95 \%$ of HIV affected individuals suffering from this type. ${ }^{2}$ HIV-2 is mainly found in West Africa but it has started to appear in Europe, USA and India. ${ }^{3}$ Compared to HIV-1, transmission of HIV-2 virus from an infected mother to her child seems to be less frequent. However, cases of transmission from an infected woman to her fetus have been reported among women who had primary HIV-2 infection during their pregnancy. ${ }^{4}$

\section{PROBLEM STATEMENT}

As per World Health Organization (WHO) statistics almost 76 million people have been affected by the disease since the beginning of the epidemic. As of 2019 there were 
38 million (31.6 million to 44.5 million) living HIV cases in the world. ${ }^{5}$ The rate of vertical transmission of HIV is as much as $15-45 \%$ without any intervention.

India has the third largest HIV epidemic in the world. In 2017 there were 2.1 million living cases of the disease in the country. ${ }^{6}$ The first case of HIV-1 was detected among sex workers in Chennai, India in $1986 .^{7}$ The first evidence of HIV-2 infection in India was provided in $1991 .^{8}$ The prevalence was slightly greater than two-fifths among females. $^{9}$ The NACO (National AIDS Control Organization) Technical Estimate Report (2015) estimated that out of 29 million annual pregnancies in India, 35,255 occur in HIV positive pregnant women. In the absence of any intervention, an estimated (2015) cohort of 10,361 infected babies will be born annually. ${ }^{10}$

\section{EFFECT}

\section{Effect of Pregnancy on HIV}

Pregnancy in HIV positive women causes a further decrease in their immunity. ${ }^{11,12}$ Studies have shown that pregnancy has little effect on asymptomatic HIV positive women. ${ }^{13,14}$ However its effect on effect on symptomatic cases has been controversial. Some studies have concluded that pregnancy does accelerate the pace of HIV whereas others have concluded that it does not. ${ }^{15,16}$ It has been found out by several studies that HIV affected pregnant women are much more likely to develop bacterial pneumonia compared to the non-pregnant ones. ${ }^{17,18,19}$

\section{Effect of HIV on pregnancy}

The effects of HIV on the outcome of pregnancy are minimal. ${ }^{20-22}$ However immunodeficiency could predispose to chorio-amnionitis with the associated risk of stillbirth and pre-term labor; the fetus could be damaged by recurrence of other infections such as cytomegalovirus or toxoplasmosis; and the effect of concurrent infections and poor nutritional status with advancing disease could impair the woman's ability to maintain her pregnancy successful. $^{23}$

\section{TRANSMISSION $24-28$}

NACO estimates the rates of vertical transmission in India to be as follows. ${ }^{29}$

Table 1: Risk factors for HIV transmission.

\begin{tabular}{|c|c|c|c|}
\hline Risk factor & Explanation & $\begin{array}{l}\text { Strength of } \\
\text { association }\end{array}$ & Impact \\
\hline \multicolumn{4}{|l|}{ Maternal } \\
\hline RNA virus load & $\begin{array}{l}\text { Higher the viral load in mother, more the chances of } \\
\text { transmission }\end{array}$ & Strong & Large \\
\hline AIDS & $\begin{array}{l}\text { If the HIV infection has progressed to AIDS, there are } \\
\text { higher chances it will be transmitted }\end{array}$ & Strong & Small-medium \\
\hline Genetic Factor & $\begin{array}{l}\text { Innate resistance or susceptibility for vertical } \\
\text { transmission maybe related to various genes present in } \\
\text { either the mother }\end{array}$ & Strong & Medium \\
\hline $\begin{array}{l}\text { Presence of other } \\
\text { conditions along } \\
\text { with HIV }\end{array}$ & $\begin{array}{l}\text { Conditions like- 1) Other Sexually transmitted infections } \\
\text { 2) Chorioamnionitis } \\
\text { 3) Vitamin A deficiency }\end{array}$ & Medium & Small \\
\hline \multicolumn{4}{|l|}{ Obstretics } \\
\hline Mode of delivery & $\begin{array}{l}\text { Traumatic or instrumental delivery increase the chances } \\
\text { of HIV transmission }\end{array}$ & Strong & Large \\
\hline $\begin{array}{l}\text { Duration of } \\
\text { membrane rupture }\end{array}$ & $\begin{array}{l}\text { It has been found that prolonged membrane rupture has } \\
\text { been (.4hours) }\end{array}$ & Strong & Large \\
\hline $\begin{array}{l}\text { RNA in } \\
\text { vagina/cervix }\end{array}$ & More likely to transmit infection & Medium & Medium \\
\hline Invasive procedures & $\begin{array}{l}\text { Invasive procedures like Chorionic villus sampling or } \\
\text { increase transmission }\end{array}$ & Strong & Small \\
\hline \multicolumn{4}{|l|}{ Pediatric } \\
\hline Prematurity & Due to various factors like lower immunity or & Strong & Strong \\
\hline Breastfeeding & $\begin{array}{l}\text { Breastfeeding or more importantly mixed feeding of } \\
\text { breastmilk and complementary feeds increase the HIV } \\
\text { risk }\end{array}$ & Strong & Large \\
\hline Genetic & $\begin{array}{l}\text { Just like maternal genetic factors, various infant risk } \\
\text { factors increase or decrease the risk of transmission }\end{array}$ & Weak & Small \\
\hline
\end{tabular}


Table 2: Rates of HIV transmission during various phases of labour, delivery and lactation.

\begin{tabular}{|l|l|}
\hline Risk factor of transmission & Rates (\%) \\
\hline During pregnancy & $5-10$ \\
\hline During labor and delivery & $10-15$ \\
\hline During breastfeeding & $5-20$ \\
\hline With breastfeeding to six months & $20-35$ \\
\hline With breastfeeding to 18-24 months & $30-45$ \\
\hline
\end{tabular}

\section{PREVENTION OF PREVENTION MATERNAL TO CHILD TRANSMISSION (PPTCT) PROGRAM}

National PPTCT program of India recognizes 4 elements to prevent HIV transmission from mother to child. ${ }^{30}$ These are-

Prong 1: Primary prevention of HIV (especially in women of childbearing age)

Prong 2: Prevent unintended pregnancy

Prong 3: Prevent transmission of HIV from the mother to their infant

Prong 4: Provide care, support and treatment to women living with HIV along with their families and children.

\section{THE PPTCT Program, India}

In an attempt to curb vertical transmission of HIV in India, The Prevention of Parent to Child Transmission of HIV/AIDS (PPTCT) program was launched in the country in the year 2002. ${ }^{29}$ The goals of the PPTCT program are-

Primary prevention of HIV, especially among women in child-bearing age.

Integration of PPTCT interventions with general health services such as basic Ante-natal Care (ANC), Natal and Post -Natal Services, Sexual Reproductive Health and Family Planning, EID, Pediatric ART and Adolescent Reproductive and Sexual Health (ARSH), TB and STI/RTI services.

Strengthening post-natal care of the HIV-infected mother and her exposed infant.

Provide the essential package of PPTCT services.

Under this program various measures have been adopted for antenatal women, women during delivery, for infected women in their post-partum period and the exposed newborns.

\section{ANTENATAL WOMEN}

All women who visit the antenatal clinic are provided information about and offered the HIV screening test. After the test, post-test counselling is very important for negative tests to remain un-infected; while for those with confirmed HIV positive tests need to be given further counselling, support and referrals to care and treatment services. ${ }^{32}$ Pregnant Women who opt-out of HIV testing should be offered repeat counselling to explore the reasons for opting out, address any misunderstandings and encourage her to reconsider her decision. These women should be offered routine HIV testing at each subsequent clinic visit. ${ }^{32}$ When a pregnant is diagnosed to be HIV positive, early registration of pregnancy (before 12 weeks) is to be done and at least 4 ANC (antenatal) checkups must be conducted during pregnancy. Screening for hemoglobin, urine analysis and blood group and type should be done. Also screening for syphilis, Hepatitis B and $\mathrm{C}, \mathrm{TB}$ and sexually transmitted diseases is also done. This is followed by nutritional counselling and iron and folic acid supplementation. ${ }^{32}$

Finally, an assessment of the clinical stage of HIV is assessed and screening for cervical cancer is done followed by providing counselling for adherence to treatment, institutional delivery and exclusive breastfeeding. ${ }^{32}$

\section{ANTIRETROVIRAL THERAPY (ART)}

All the pregnant women diagnosed with HIV are started on TRIPLE DRUG ART (Tenofovir+ Lamivudine + Efavirenz) irrespective of their CD4 count and WHO clinical stage. As per NACO, in 2018, out of all the pregnant women diagnosed with HIV, $60 \%$ were taking ART. ${ }^{32}$

Table 3: ART drugs with dose and side effect.

\begin{tabular}{|lll|}
\hline $\begin{array}{l}\text { Name of the } \\
\text { drug }\end{array}$ & Dose & $\begin{array}{l}\text { Side-effects } \\
\text { Tenofovir }\end{array}$ \\
\hline Lamivudine & $300 \mathrm{mg}$ & $\begin{array}{l}\text { Nephrotoxicity } \\
\text { Hypo-phosphataemia }\end{array}$ \\
\hline Efavirenz & $600 \mathrm{mg}$ & $\begin{array}{l}\text { Hypersensitivity } \\
\text { Pancreatitis (rare) }\end{array}$ \\
\hline
\end{tabular}

ART has been proven to provide several advantages like delaying disease progression, preventing severe opportunistic infections, reducing transmission rates of HIV and increasing the survival rate. ${ }^{31}$ A combination of 3 drugs is used for ART as it helps restore immunity, causes maximum viral suppression, prevents emergence of resistance and improves the overall quality of life. ${ }^{33}$

\section{INTRAPARTUM CARE}

\section{Precautions during labour}

Various precautions that need to be taken during labor include conducting minimal vaginal examinations, giving ART to the mother, avoiding ARM and invasive fetal 
monitoring and oxytocic drugs should be used for prevention of blood loss. ${ }^{33}$

Episiotomy and prolonged traumatic delivery should be avoided as far as possible. If instrumental delivery is indicated, applying forceps should be preferred over ventouse. Early cord clamping should be done. All the Universal Safety Precautions should be followed while conducting the delivery. ${ }^{33}$

\section{Role of LSCS}

Various studies and analyses have been conducted, so as to assess the role of elective Lowe Segment Caesarean section (LSCS) the deliveries of HIV positive women and to assess if they have an advantage over vaginal delivery.

In a European study, the HIV status of 370 infants born to HIV positive mothers was studied. 200 of the women had had a vaginal delivery and 170 of them had an LSCS. As per the results of the study, the rate of transmission in the former was $10.5 \%$ and the latter was $1.8 \% .{ }^{34} \mathrm{~A}$ metaanalysis of several North American and European studies showed that the rates of HIV transmission were reduced by as much as 50 percent in HIV positive in whom LSCS was conducted instead of a vaginal delivery. ${ }^{35}$ In a metaanalysis of studies in middle- and low-income countries it was found that though LSCS increased the morbidity in HIV positive mothers, it was associated with a reduction in transmission rates with an Odd's ratio -0.27 (95\% CI 0.16 to 0.45$)$. $^{36}$

There are various guidelines by different organizations about whether elective LSCS must be carried out in HIV affected women.

Table 5: Guidelines for conducting elective LSCS in HIV positive patients.

\begin{tabular}{|c|c|}
\hline $\begin{array}{l}\text { NACO } \\
\text { guidelines }\end{array}$ & $\begin{array}{l}\text { LSCS only for obstetric } \\
\text { indications }\end{array}$ \\
\hline US guidelines & $\begin{array}{l}\text { Scheduled Cesarean delivery at } 38 \\
\text { weeks of gestation provided HIV } \\
\text { RNA levels are }>1000 \text { copies } / \mathrm{ml} \text { or } \\
\text { are unknown at the time of delivery. } \\
36\end{array}$ \\
\hline $\begin{array}{l}\text { BHIVA } \\
\text { guidelines } \\
\text { (2012) }\end{array}$ & $\begin{array}{l}\text { Offer C-section to women not on } \\
\text { ART and have viral load }>400 \\
\text { copies/ml or higher. } 37\end{array}$ \\
\hline
\end{tabular}

The risk of transmission increases by $2 \%$ per hour after rupture of membranes There is no benefit of C-Section after 4 hours of delivery. ${ }^{39}$

\section{POSTPARTUM CARE}

Neonatal (Anti-retroviral) ARV prophylaxis is given for 6 weeks, to infants born to HIV positive mothers, regardless of whether they are breastfed or not. ${ }^{4} \mathrm{~A}$ blind trial conducted in the African countries of South Africa,
Uganda, Zimbabwe and Tanzania among 1522 HIV negative infants, born to HIV positive mothers, it was found that transmission rates reduced by $76 \%$ in infants who received the prophylaxis. ${ }^{40}$ Cotrimoxazole prophylaxis is given to infants from 6 weeks to 18 months of age (up to 5 years if they are HIV positive). ${ }^{41}$

\section{Infant feeding}

As per the PPTCT guidelines for breastfeeding, exclusive breast feeding should be done for at least 6 months, after which complementary feeding should introduced gradually, irrespective of whether the infant is diagnosed HIV negative or positive by early infant diagnosis. Also, either mother or infant should be receiving ARV prophylaxis or ART during the whole duration of breast feeding. ARV prophylaxis should continue for one week after the breast feeding has fully stopped. ${ }^{42}$ For breast feeding infants diagnosed HIV negative, breast feeding should be continued until 12 months of age, if the mother is on ART or ARV prophylaxis is being given to mother or infant. For infants diagnosed HIV positive, ART should be started and breast feeding should be continued till 2 years of age. ${ }^{42}$

Breast feeding should stop once a nutritionally adequate and safe diet without breast-milk can be provided. Breast feeding should never be stopped abruptly. Mothers who decide to stop breast feeding should stop gradually over one month. ${ }^{42}$

\section{CONCLUSION}

Thus, HIV is a potentially dangerous diseases that can have profound effects on pregnancy Women can pass on this disease to the fetus or child while they are pregnant or lactating. In order to reduce these rated the PPTCT program has been launched by NACO in India. Seropositive women are given Triple Dose Anti Retroviral therapy that comprises of Tenofovir, Lamivudine and Efavirenz. Also, special precautions adopted while conducting their delivery. Whether or not LSCS is to be performed depends on the indications and on which guidelines are followed. Finally, infant- feeding is advised to be carried out as per the guidelines stated in the PPTCT act so as to minimize the chances of HIV transmission to the infant. The introduction of these all these guidelines under the National PPTCT program has resulted in the rates of HIV transmission rates from mother to child reducing significantly

\section{Funding: No funding sources \\ Conflict of interest: None declared \\ Ethical approval: Not required}

\section{REFERENCES}

1. Avert- Global information and education on HIV and AIDS: Information on HIV. 2019. Available at: 
www.avert.org/professionals/hiv-science/typesstrains. Last accessed on1st December, 2020.

2. Centers for disease control and prevention: HIV basics. Available

https://www.cdc.gov/hiv/basics/whatishiv.html. Last accessed on 1st December, 2020.

3. Campbell-Yesufu OT, Gandhi RT. Update on human immunodeficiency virus (HIV)-2 infection. Clin Infect Dis. 2011;52(6):780-87.

4. Agrawal S, Sawant S, Shastri J. Prevalence of HIV-2 infection in Mumbai. Indian J Dermatol Venereol Leprol. 2010;76:709-10.

5. Deaths. World Health Organization. World Health Organization. 2021. Available from: https://www.who.int/gho/hiv/epidemic_status/cases_ all/en/. Last accessed on 1st January, 2021.

6. AIDSinfo | UNAIDS. Aidsinfo.unaids.org. 2021. Available from: http://aidsinfo.unaids.org/. Last accessed on 1st January, 2021.

7. EA S, PG B, TJ J, S N, S S, CS L. Evidence for HTLV-III infection in prostitutes in Tamil Nadu (India) [Internet]. PubMed. 2021. Available from: https://www.ncbi.nlm.nih.gov/pubmed/3623641. Last accessed on 21st December, 2021.

8. Weber S, Moriniere V, Knüppel T, Charbit M, Dusek J, Ghiggeri G et al. Prevalence of Mutations in Renal Developmental Genes in Children with Renal Hypodysplasia: Results of the ESCAPE Study. 2021.

9. HIV Estimations 2017 Report. Naco.gov.in. 2021. Available

from: http://naco.gov.in/sites/default/files/HIV\%20Estimati ons\%202017\%20Report_1.pdf. Last accessed on 14th November, 2020.

10. HIV Estimations 2017 Report. Naco.gov.in. 2021. Available from:

11. http://naco.gov.in/sites/default/files/India\%20HIV\%2 0Estimations\%202015.pdf. Last accessed on 14 November, 2020.

12. Jensen L, O'Sullivan M, Gomez-del-Rio M, Setzer E, Gaskin C, Penso C. Acquired immunodeficiency (AIDS) in pregnancy. American Journal of Obstetrics and Gynecology. 1984;148(8):1145-146.

13. Minkoff H, Nanda D, Menez R, Fikrig S. Pregnancies resulting in infants with acquired immunodeficiency syndrome or AIDS-related complex. International Journal of Gynecology \& Obstetrics. 1988;26(1):161.

14. Bukusi E. Effect of Human Immunodeficiency Virus Type 1 Infection upon Acute Salpingitis: A Laparoscopic Study [Internet]. Academia.edu. 2021. Available from: https://www.academia.edu/14101579/Effect_of_Hu man_Immunodeficiency_Virus_Type_1_Infection_u pon_Acute_Salpingitis_A_Laparoscopic_Study. Last accessed on 14 September, 2020.

15. Johnstone FD. Pregnancy outcome and pregnancy management in HIV-infected women. In: Johnson MA, Johnstone FD (eds). HIV Infection in women. Edinburgh, Churchill Livingstone. 1993:187-198.

16. Hocke C, Morlat P, Chene G. The Groupe d'epidemiologie clinique du SIDA en Aquitaine.
Prospective cohort study of the effect of pregnancy in the progression of human immunodeficiency virus infection. Obstet Gynecol. 1995;86(6):886-91.

17. Brettle RP, Raab GM, Ross A, Fielding KL, Gore SM, Bird AG. HIV infection in women: immunological markers and the influence of pregnancy. AIDS. 1995;9:1177-1184.

18. Weisser M, Rudin C, Battegay M, Pfluger D, Kully C, Egger M. The Swiss HIV Cohort Study (SHCS), and the Swiss Collaborative HIV and Pregnancy Study (SCHPS). Does pregnancy.

19. Rich KC, Siegel JN, Jennings c. CD4+ lymphocytes in perinatal human immunodeficiency virus (HIV) infection: evidence for pregnancy-induced immune depression in uninfected and HIV-infected women. J Infect Dis. 1995; 172:1221-227.

20. Schaefer A, Grosch-Woerner I, Friedman W. The effect of pregnancy on the natural course of HIV infection. IV International Conference on AIDS, Stockholm. 1988;4039.

21. Bakas C, Zarou DM, de Caprariis PJ. First-trimester spontaneous abortions and the incidence of human immunodeficiency virus seropositivity. J Reprod Med. 1996;41(1):15-18.

22. Johnstone FD. HIV and pregnancy. $\mathrm{Br} \mathrm{J}$ Obstet Gynaecol. 1996;103:1184-190.

23. Brocklehurst P, French R. The association between maternal HIV infection and perinatal outcome: a systematic review of the literature and meta-analysis. British Journal of Obstetrics and Gynaecology. 1998;105:839-48.

24. The effect of HIV infection on pregnancy outcome. Redirecting. Available from: https://doi.org/10.1016/S0950-3552(05)80118-X. Last accessed on 14 September, 2020.

25. Mother-to-child transmission of HIV [Internet]. World Health Organization. World Health Organization; 2019. Available from: https://www.who.int/hiv/topics/mtct/about/en/. Last accessed on 7th December, 2020.

26. Newell ML. Prevention of mother-to-child transmission of HIV: challenges for the current decade. Bull World Health Organ. 2001;79(12):113844.

27. Ellington SR, King CC, Kourtis AP. Host factors that influence mother-to-child transmission of HIV-1: genetics, coinfections, behavior and nutrition. Future Virol. 2011;6(2):1451-69.

28. Andany N, Letchumanan M, Bondy L, Murphy K, Loutfy MR. Amniocentesis in the HIV-infected pregnant woman: Is there still cause for concern in the era of combination antiretroviral therapy? Can J Infect Dis Med Microbiol. Autumn. 2013;24(3):e91-5.

29. HIV transmission through breastfeeding [Internet]. Who.int. Available from: https://www.who.int/nutrition/publications/HIV_IF_ Transmission.pdf. Last accessed on 7th December, 2020.

30. Prevention of Parent to Child Transmission (PPTCT). Available from: http://naco.gov.in/prevention-parent- 
child-transmissionpptct. Last accessed on 7 th December, 2020.

31. National guidelines for PPTCT. Available from: http://naco.gov.in/prevention-parent-childtransmissionpptct. Last accessed on 7 th December, 2020.

32. Prevention of Parent to Child Transmission (PPTCT) of HIV using Multi Drug Anti-retroviral Regimen in India. Available from: http://naco.gov.in/sites/default/files/National_Guideli nes_for_PPTCT_0.pdf. Last accessed on 7th December, 2020.

33. National AIDS Control Organization and ICMRNational Institute of Medical Statistics. HIV Estimations 2017: Technical Report. New Delhi: NACO, Ministry of Health and Family Welfare, Government of India, 2018. Available at: http://naco.gov.in/sites/default/files/HIV\%20Estimati ons\%202017\%20Report_1.pdf. Last accessed on 7th December, 2020.

34. Multi Drug Anti-retroviral Regimen. Available from: http://naco.gov.in/prevention-parent-childtransmissionpptct. Last accessed on 7th December, 2020.

35. European Mode of Delivery Collaboration. Elective caesarean-section versus vaginal delivery in prevention of vertical HIV-1 transmission: a randomised clinical trial. Lancet. 1999;353(9158):1035-039.

36. Andiman W, Bryson Y. The mode of delivery and the risk of vertical transmission of human immunodeficiency virus type 1--a meta-analysis of 15 prospective cohort studies. $\mathrm{N}$ Engl $\mathrm{J}$ Med. 1999;340(13):977-87.

37. Kennedy CE, Yeh PT, Pandey S, Betran AP, Narasimhan M. Elective cesarean section for women living with HIV: a systematic review of risks and benefits. AIDS. 2017;31(11):1579-591.
38. HIV/AIDS Treatment Guidelines [Internet]. Nih.gov. Available from: http://aidsinfo.nih.gov/guidelines. Last accessed on 7th December, 2020.

39. BHIVA guidelines for the management of HIV in pregnancy and postpartum 2018 (2020 third interim update) [Internet]. Bhiva.org. Available from: https://www.bhiva.org/pregnancy-guidelines. Last accessed on 14th November, 2020.

40. Peters H, Byrne L, De Ruiter A, Francis K, Harding $\mathrm{K}$, Taylor GP, et al. Duration of ruptured membranes and mother-to-child HIV transmission: a prospective population-based surveillance study. BJOG. 2016;123(6):975-81.

41. Six months of nevirapine prophylaxis for breastfeeding infants reduces transmission by $76 \%$ if mother not on ART [Internet]. Aidsmap.com. Available from: https://www.aidsmap.com/news/mar-2011/sixmonths-nevirapine-prophylaxis-breastfeedinginfants-reduces-transmission-76-if. Last accessed on 24 December, 2020.

42. Percentage of infants born to HIV-infected women who are started on cotrimoxazole prophylaxis within two months of birth [Internet]. Unaids.org. Available from:

https://indicatorregistry.unaids.org/indicator/percenta ge-infants-born-hiv-infected-women-who-arestarted-cotrimoxazole-prophylaxis. Last accessed on 22 December, 2020.

43. Pm 07/01/13 5:22. For HIV-exposed and infected children [Internet]. Gov.in. Available from: http://www.naco.gov.in/sites/default/files/Paedia\%20 Nutrition\%20national\%20guidelines\%20NACO.pdf. Last accessed on 01 October, 2020.

Cite this article as: Kore GS. HIV in pregnancy. Int J Reprod Contracept Obstet Gynecol 2021;10:12416. 